\title{
Linking Information Sharing And Supplier Network Responsiveness With Delivery Dependability Of A Firm
}

Ashish A. Thatte, Gonzaga University, USA

Vikas Agrawal, Fayetteville State University, USA

Shahnawaz Muhammed, Fayetteville State University, USA

\begin{abstract}
The twenty first century organization is required to provide accurate on time deliveries in addition to providing high quality products at low costs. This can be achieved if various processes within and between the organizations are streamlined and well defined. Several studies have indicated the significance of various manufacturing (or internal) practices that are instrumental in creating time-based competitive capability. Collaborative relations and information sharing practices with suppliers have long been believed to positively impact the responsiveness and delivery performance of organizations and supply chains. Responsive suppliers can play a key role in affecting a firm's own delivery performance. This research investigates and tests the relationships between information sharing practices of a firm, supplier network responsiveness, and delivery dependability of a firm. The large scale web-based survey yielded 294 responses from industry professionals in the manufacturing and supply chain area. The proposed relationships were tested using structural equation modeling. The research findings point out that higher level of information sharing practices can lead to improved supplier network responsiveness, and higher levels of supplier network responsiveness can have a direct positive impact on delivery dependability of a firm. The implications of our findings are discussed and directions for future research are provided.
\end{abstract}

Keywords: Supplier responsiveness, Supply chain management, Information sharing, Delivery dependability, structural equation modeling

\section{INTRODUCTION}

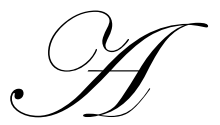

s competition in the $21^{\text {st }}$ century intensifies, organizations are required to provide superior quality products, at low costs, with on-time and reliable delivery performance. In today's global competitive market delivery dependability is considered an order qualifier along with quality and price of a product. Organizations are looking at ways to achieve these requirements by adopting various intra and inter-organizational practices. Amela et al. (2008) contend that the coordination among functional areas within the buying firm as well as between buyer firms and their key suppliers are extremely important in order to improve the product reliability and overall product quality performance. Ryu and Cook (2005) emphasize the importance of long-tem orientation culture in managing effective interfirm relationships in the supply chain. They contend that such long-term orientations between supply chain members will be a key in determining the success of the evergrowing cadre of the international businesses.

Further, the shift from traditional manufacturing and purchasing to JIT manufacturing and purchasing requires customers and suppliers to shift from adversarial relationships to strategic partnerships, and information sharing, so as to attain flexibility, reliability, and speed (Frohlich and Westbrook, 2001; Clinton and Closs, 1997). Supplier collaboration and information sharing is considered as a key to attaining customer responsiveness, and creating value for both buyers and suppliers (Rossetti and Choi, 2005; Peleg et al., 2002; Monzka et al., 1998; 
DeToni and Nassimbeni, 1999). It has been argued that the reliability and responsiveness of suppliers plays an important role in the shortening a firm's delivery cycle (Srivastava, 2006) thus making deliveries more dependable. If suppliers are inefficient and less responsive, this could slow down the flow of goods through the supply chain resulting in poor-delivery performance and poor-quality customer service of the downstream firm which is much dependent on its suppliers. It is the intent of this study to investigate whether supplier responsiveness impacts a firm's delivery dependability.

The current research investigates the effect of information sharing on supplier network responsiveness and delivery dependability of a firm. Thus by providing empirical evidence of the said relationships, this study offers useful guidelines for measuring and improving the delivery performance of a firm, facilitating further research in the area.

Supplier network responsiveness is a new construct developed in this research based on extensive review of extant literature in manufacturing flexibility and agility, supply chain flexibility and agility, and customer responsiveness. The measurement instruments for the information sharing ( $\mathrm{Li}$ et al., 2005; Li et al., 2006), and delivery dependability (Koufteros et al., 1997) in the proposed model are adopted with modifications from earlier studies. The newly developed instrument is then tested empirically, using data collected from respondents to a survey questionnaire. Structural equation modeling is used to test the hypothesized relationships.

The remainder of the paper is organized as follows. Section two presents the research framework, provides definitions and theory for the constructs, and develops the hypothesized relationships. The research methodology, empirical validation, and analysis of results are then presented. The last couple of sections present the findings and implications of the study and provide directions for future work.

\section{CONSTRUCTS AND RESEARCH FRAMEWORK}

Fig. 1 presents the framework developed in this research. The research framework proposes that information sharing has an impact on delivery dependability both directly and indirectly through supplier network responsiveness. Information sharing and delivery dependability are concepts that have been operationalized in the existing literature ( $\mathrm{Li}$ et al., 2005, 2006; Koufteros et al., 1997). A detailed description of the development of the supplier network responsiveness construct is provided in the following paragraphs. The expected relationships among information sharing, supplier network responsiveness, and delivery dependability are discussed with supporting literature review. Table 1 lists the three constructs used in this study along with their definitions and supporting literature. Hypotheses relating these variables are further developed.

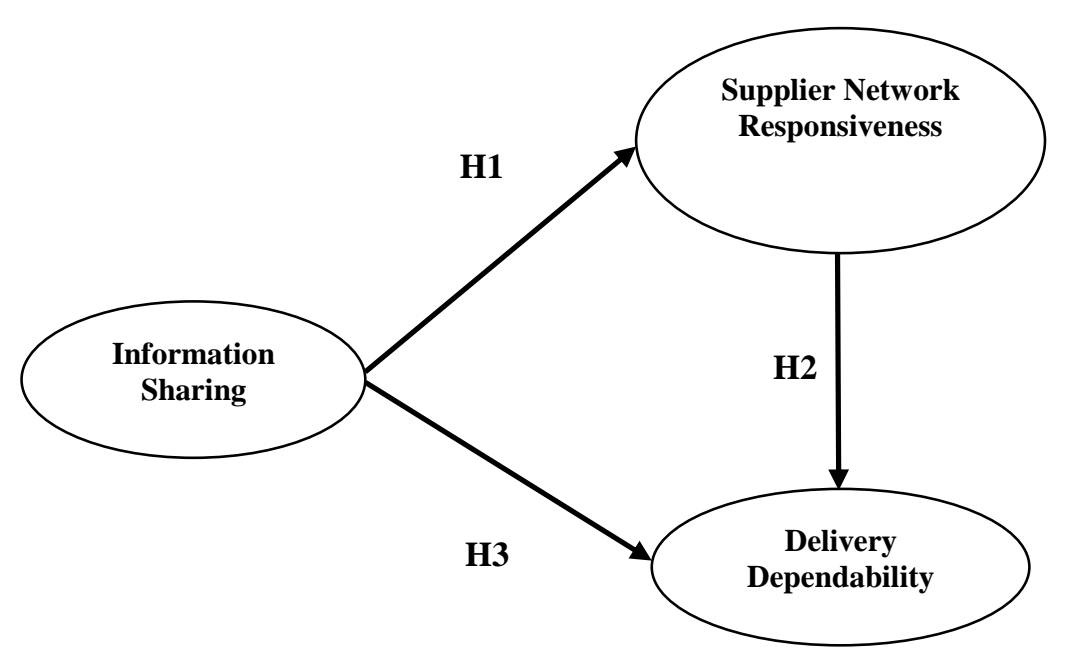

Figure 1: Research framework 


\subsection{Information Sharing}

Information sharing refers to "the extent to which critical and proprietary information is communicated to one's supply chain partner" ( $\mathrm{Li}$ et al., 2006, p. 110). It refers to the access to private data between trading partners thus enabling them to monitor the progress of products and orders as they pass through various processes in the supply chain (Simatupang and Sridharan, 2002). Shared information can vary from strategic to tactical in nature and could pertain to logistics, customer orders, forecasts, schedules, markets, or more (Mentzer et al., 2000). Some of the elements that comprise information sharing include data acquisition, processing, storage, presentation, retrieval, and broadcasting of demand and forecast data, inventory status and locations, order status, cost-related data, and performance status (Simatupang and Sridharan, 2005). Information sharing pertaining to key performance metrics and process data improves the supply chain visibility thus enabling effective decision making. Information shared in a supply chain is of use only if it is relevant, accurate, timely, and reliable (Simatupang and Sridharan, 2005). Information sharing with trading partners enables organizations to make better decisions and to take actions on the basis of greater visibility (Davenport et al., 2001), thus making the supply chain competitive (Lummus and Vokurka, 1999).

In recent years, uncertainties have become a greater concern in supply chains, consequently increasing inventories and distorting demand forecasts. This distortion amplifies as we move upstream in the supply chain - the well known bullwhip effect (Lee et al., 1997). Through information sharing, the demand information flows upstream from the point of sales, while product availability information flows downstream (Lee and Whang, 2001; Yu et al., 2001) in a systematic manner. Yu et al. (2001) point out that the negative impact of the bullwhip effect on a supply chain can be reduced or eliminated by sharing information with trading partners. Technology like Radio Frequency Identification (REID) systems could be used to greatly improve supply chain visibility. Narsing (2005) suggested that RFIDs permit an organization`s supply chain to have increased product visibility, reduction of stock, trim warehouse costs, eliminate stock errors, reduce theft and shrinkage and allow them to update their logistics and inventory databases with real-time information. Moreover, information sharing ensures that the right information is available for the right trading partner in the right place and at the right time (Liu and Kumar, 2003). Lalonde (1998) regards information sharing as a key to creating a competitive supply chain.

\subsection{Supplier Network Responsiveness}

Responsiveness is defined as the capability of promptness and the degree to which an entity (firm / supply chain) can address changes in customer demand (Holweg, 2005; Prater et al., 2001; Lummus et al., 2003; Duclos et al., 2003). Supplier network responsiveness is defined as the ability of a firm's major suppliers to address changes in the firm's demand. A key to responsiveness is the presence of responsive and flexible partners upstream and downstream of the focal firm (Christopher and Peck, 2004). The ability of firms to react quickly to customer demand is dependent on the reaction time of suppliers to make volume changes.

Whenever disruptive causes such as new technology, terrorist threats (Walker, 2005) or cut-throat competition tend to throw the supply chain haywire, the supply chain networks must be ready to react to any ripple effect. Slack (1991) argues that supplier networks are the essential building blocks of a flexible system. Some interviews with operations managers conducted at the European vehicle assembly plants of Volvo revealed that the lack of supplier network flexibility hampered the company's responsiveness (Holweg, 2005). Holweg and Pil (2001) argue that flexibility in the supplier network is an important ingredient of being responsive to changes in customer demand. In order to be responsive the organizations should be able to select suppliers who can add new products and make desired changes quickly.

Manna (2008) suggested that the relationships with suppliers are vital to the success of organizations regardless of the industry. Burt and Soukup (1985) suggested that failure to include suppliers' inputs in product development is a vulnerable aspect of supply chain management. McGinnis and Vallopra (1999) found that involving suppliers could make new product development a success. Cheraghi et al. (2004) stated that the effective supplier evaluation and purchasing processes are of vital importance for organizations to succeed in today's global dynamic economy and citied many critical success factors for supplier selection. Karpak et al. (1999) contend that supplier selection by organizations in a supply chain management environment is inherently a multi-objective 
problem. They discussed a multiple criteria decision support system, called Visual Interactive Goal Programing (VIG) to assist purchasing teams in their vendor selection decisions. Fisher et al. (2000) found that for short lifecycle products, such as fashion apparel, retailers are most successful if they can work with suppliers who can provide initial shipments of product based on forecasts, but then rapidly increase production to the right style, color, size, etc. based on actual sales. They note that fast supply chains can produce products as they sell rather than worrying about accurate forecasts. These studies suggest that supplier selection based on product development capabilities and rapid deployment capabilities positively impact the delivery time of new products. Choi and Hartley (1996) found that the capability of suppliers to make product volume changes was a significant factor in supplier selection in the automotive industry. In certain industries such as in hi-tech and electronics, demand volatility poses a unique challenge to suppliers to vary output in line with demand. The increases or decreases in demand may come at a short notice and need to be sustained over some time period. Some of the measures of supplier network responsiveness include major suppliers' ability to: change product volume in a relatively short time, change product mix in a relatively short time, consistently accommodate the firm's requests, provide quick inbound logistics to the firm, have outstanding on-time delivery record, and effectively expedite emergency orders.

\subsection{Delivery Dependability}

Nair (2005) defines delivery dependability as the ability to meet quoted or anticipated delivery dates and quantities on a consistent basis. Hall et al. (1991) define dependability as consistently performing at the time scheduled or promised. According to Blackburn (1991), delivery dependability is the ability of an organization to have accurate and reliable deliveries. Koufteros et al. (2002) define delivery dependability as "the extent to which the manufacturing enterprise is capable of meeting customer delivery requirements" (p. 266). Summarizing the above definitions, we define delivery dependability as the ability of an organization to provide on time the type and volume of product required by customer(s).

Delivery capability is of great importance due to the current global nature of business and the shift towards Just-in-Time (JIT) practices (Koufteros et al., 2002, Milgate, 2000) by organizations. Hill (2000) states that "if companies continue to miss due dates, customers will increasingly stop considering them as potential suppliers, leading to loss of market share or even the whole business" (p. 60). These firms will need to improve upon their delivery dependability without which they may not get a chance to compete in the marketplace (Hill, 2000). Thus the timing and reliability of the delivery is as important as the quantity being delivered (Maskell, 1991). Thus in today's competitive business environment, delivery dependability is considered as an order qualifier in addition to product quality and price.

Past literature has consistently identified delivery dependability as a key competitive capability along with cost, quality, time-to-market, product innovation, and product and volume flexibility (ex: Nemetz, 1990; Roth and Miller, 1990; Ferdows and DeMeyer, 1990; Koufteros, 2002; Shapiro, et al., 1982; Bowersox, et al., 1989; Fawcett et al., 1997). Delivery dependability includes on-time delivery, order fill rate, frequency of delivery, and delivery speed (Zhang et al., 2002).

In an international case study involving Australian and Singaporean firms, Soosay and Chapman (2006) found that majority of the organizations treated on-time delivery as the most important indicator of delivery performance of a firm. Supply chain effectiveness and efficiency is also evaluated on the basis of accurate, on-time deliveries (Koufteros et al., 2002, Milgate, 2000). Delivery dependability has been shown to positively and significantly impact performance (ex: Fawcett et al., 1997). In an empirical study of manufacturing firms, Fawcett et al. (1997) found that delivery reliability was voted as the second most significant logistic strategic priority (after quality, and ahead of logistics flexibility, cost leadership, and service innovation). They also found that delivery dependability (in terms of due-date performance) was the third most significant manufacturing related priority (after quality and cost, and ahead of flexibility and innovation). This brings out the uncontested significance of delivery dependability as a critical and vital source of competitive advantage in today's competitive business world. Table 1 summarizes all the constructs definitions and supporting literature. 
Table 1

Constructs definitions with supporting literature

\begin{tabular}{lll}
\hline Sub-constructs & \multicolumn{1}{c}{ Definitions } & Literature \\
\hline $\begin{array}{l}\text { Information } \\
\text { Sharing }\end{array}$ & $\begin{array}{l}\text { "The extent to which critical and } \\
\text { proprietary information is communicated } \\
\text { to one's supply chain partner" (Li et al., } \\
\text { 2006, p. 110) }\end{array}$ & $\begin{array}{l}\text { Li et al., 2005; Monczka et al., 1998; Mentzer et al., 2000, } \\
\text { Stein and Sweat, 1998, Yu et al., 2001; Towill, 1997; } \\
\text { Balsmeier and Voisin, 1996; Jones, 1998; Lalonde, 1998; } \\
\text { Vokurka and Lummus, 2000; Lancioni et al., 2000; Ballou et } \\
\text { al., 2000. }\end{array}$ \\
$\begin{array}{ll}\text { Supplier Network } \\
\text { Responsiveness }\end{array}$ & $\begin{array}{l}\text { The ability of a firm's major suppliers to } \\
\text { address changes in the firm's demand }\end{array}$ & $\begin{array}{l}\text { Prater et al., 2001; Lummus et al., 2003; Duclos et al., 2003; } \\
\text { Jordan and Michel, 2000; Rich and Hines, 1997; Burt and } \\
\text { Soukup, 1985; McGinnis and Vallorpa, 1999; Fisher et al., } \\
\text { 2000; Bensaou, 1999; Mason et al., 2002; Cooper and }\end{array}$ \\
$\begin{array}{ll}\text { Delivery } \\
\text { Dependability }\end{array}$ & $\begin{array}{l}\text { Gardner, 1993; Choi and Hartley, 1996 } \\
\text { "The ability of an organization to provide } \\
\text { on time the type and volume of product } \\
\text { required by customer(s)" (Li et al., 2006, 2005; Hall, 1993, Koufteros et al., 1997; Rondeau et } \\
\text { p. 120) }\end{array}$ & $\begin{array}{l}\text { al., 2000 } \\
\end{array}$ \\
\hline
\end{tabular}

\section{$2.4 \quad$ Research Hypotheses}

There is wide agreement in the literature that building trust and sharing information with supply chain partners is essential for the focal firms' effectiveness and efficiency (ex: Tan 2002; Srivastava, 2006). Hoetker et al. (2007) contend that a long term relationship between and information sharing with trading partners improves performance of both buyers and suppliers. The development of relationship-specific routines creates value in longterm relationship with suppliers (Singh and Mitchell, 1996; Asanuma, 1989). Information sharing would be a critical component of this relationship-specific routine that is aimed at creating value within the supply chain, in terms of quality products at lower costs and improved responsiveness. The flow of accurate and timely information in the supply chain is as important as the flow of goods. Information sharing can provide flexibility and improve the supply chain responsiveness (Golden and Powell, 1999; Fredericks, 2005; Gosain et al., 2005; Lummus et al., 2005; Schmenner and Tatikonda, 2005) by reducing bullwhip effect (Lee et al., 1997; Van der Vorst and Beulens, 2002) along with other benefits such as better customer service, improved trust between parties, and reduced inventories. In an empirical study of a supply chain of a manufacturing companies and a grocery network, Golden and Powell (1999) found that the level of flexibility and responsiveness achieved along the entire chain depends on the extent of information shared. JIT purchasing from and delivery by suppliers is one of the vital benefits and outcome of information sharing. Information sharing with suppliers significantly contributes towards creating seamless operations and reducing difficulties (Bowersox, 1990; Ballou, et al. 2000) and uncertainty in the supply chain. Thus, accurate and timely information sharing with suppliers can boost the suppliers' ability to respond rapidly and accurately by improving suppliers' production (Milgate, 2000) and capacity planning. Based on the above it is hypothesized that:

Hypothesis 1: Firms with high levels of information sharing practices will have high levels of supplier network responsiveness.

Many companies depend on supplier deliveries instead of stocking large quantities of inventories (Koufteros et al., 2002). Responsive suppliers will have a positive influence on the responsiveness of a firm. Any inefficiency at the upstream end of the supply chain will be transmitted to the downstream firm and to the customer in turn. By having responsive suppliers, a firm is assured of on-time and accurate deliveries from suppliers thereby directly influencing its own delivery performance. In other words if supplier responsiveness is high, it would contribute towards improving the firm's own delivery performance manifested in greater delivery dependability. This can also provide a firm with other competitive capabilities such as reduced time-to-market. Brown and Vastag (1993) point out that delivery is the culmination of a set of upstream operations. Milgate (2000) found that late deliveries by suppliers significantly predicted the late deliveries of the immediate downstream firm (in terms of lead time and throughput times). This implies that supplier responsiveness significantly predicts the delivery speed and reliability of a firm. The above arguments lead to: 
Hypothesis 2: The higher the level of supplier network responsiveness, the higher the level of delivery dependability of a firm.

In an empirical research on benefits and risks of commitment strategy with suppliers, Swink and Zsidisin (2006) found that focused commitment including developing mutual trust and long term relations (which would include in part information sharing with suppliers for effective decision making) leads to improved delivery performance (including delivery speed and delivery dependability among others) for the firm.

Sharing information (and data) with other parties within the supply chain can be used as a source of competitive advantage (Jones, 1998; Novack et al., 1995) on various dimensions such as cost, quality, delivery dependability, product innovation, and time-to-market. Furthermore, Tompkins and Ang (1999) consider the effective use of pertinent, timely, and accurate information by supply chain members as a key competitive factor. Information sharing with suppliers has given Dell Corp. the benefits of faster cycle times, reduced inventory, and improved forecasts. The above arguments lead to:

Hypothesis 3: Firms with high levels of information sharing practices will have high levels of delivery dependability.

\section{RESEARCH METHODOLOGY}

Research methods are described for the instrument development and structural modeling. The instrument development methodology for supplier network responsiveness includes four stages: (1) item generation, (2) prepilot study, (4) pilot study, and (4) large-scale data analysis. Instruments for information sharing and delivery dependability have been adopted from $\mathrm{Li}$ et al. $(2005,2006)$ and Zhang (2001) respectively. The items for these instruments along with the supplier network responsiveness instrument are listed in Appendix A.

\subsection{Item Generation, Pre-Pilot, And Pilot Study}

As per Churchill (1979), the content validity is enhanced if steps are taken to ensure that the domain of the construct is covered. In accordance with Churchill (1979), in the item generation stage, potential items were generated through a literature review and from construct definitions. The items for supplier network responsiveness were generated through supply chain flexibility literature, manufacturing flexibility literature, supply chain agility literature, agile manufacturing literature, and customer responsiveness literature (Prater et al., 2001; Lummus et al., 2003; Duclos et al., 2003; Van Hoek, 2000; Fawcett, 1992; Fawcett et al., 1996; Fawcett and Smith, 1995; Lau, 1999; Emerson and Grimm, 1998; Martin and Grbac, 2003).

In the pre-pilot study, these items were reviewed by six academicians and a doctoral student, and further reevaluated through a structured interview with one high level executive. The focus was to check the relevance of each construct's definition and clarity of wordings of sample questionnaire items. Based on the feedback from the academicians and practitioners, redundant and ambiguous items were either modified or eliminated. New items were added whenever deemed necessary. Definitions were also modified to ensure that the domain of the construct is covered and thus strengthen the content validity.

For the pilot study phase, the Q-sort method was used to pre-assess convergent and discriminant validity of the scales. This study is a part of a bigger study involving a second-order construct which is comprised of three dimensions (supplier network responsiveness being one of them). Purchasing/materials/supply chain/operations vice presidents and managers were requested to act as judges and sort the items (of the three sub-constructs) into the three dimensions of the second order construct, based on similarities and differences among items. An indicator of construct validity was the convergence and divergence of items within the categories. If an item was consistently placed within a particular category, then it was considered to demonstrate convergent validity with the related construct, and discriminant validity with the others. The reliability of the sorting conducted by the judges was assessed using three different measures: the inter-judge raw agreement scores, Cohen's Kappa (Cohen, 1960), and item placement ratios (or Moore and Benbasat's (1991) "Hit Ratio"). The inter-judge raw agreement scores were calculated by counting the number of items both judges agreed to place in a certain category. An item was 
considered as an item with agreement, though the category in which the item was sorted together by both judges may not be the originally intended category. Further, Cohen's Kappa was used to eliminate any chance agreements, thereby evaluating the true agreement score between two judges. Finally, item placement ratios were calculated by counting all the items that were correctly sorted into the target category by the judges for each round and dividing them by twice the total number of items.

The process was carried out in three rounds, with the procedure being repeated for each round. Based on the misplacements made by the judges and the feedback obtained from them, modifications in construct definitions and/or modification/addition/deletion of items were carried out at the end of each round, and before entering into the successive round. The third sorting round was used to re-validate the constructs. The results of the third round were similar to those obtained in the second sorting round, thereby indicating consistency of results between the second and third round. At this stage, the results suggested an excellent level of inter-judge agreement, indicating a high level of reliability and construct validity (at the pilot stage) for the newly developed construct supplier network responsiveness.

\subsection{Large-Scale Methods}

Since this study has a supply chain management focus, the target respondents were vice presidents, directors and managers in operations, manufacturing, purchasing, logistics, materials, and supply chain areas as these personnel were deemed to have the best knowledge in the supply chain area. The respondents were asked to refer to their major suppliers or customers when answering the questionnaire. The e-mail lists were purchased from three different sources. These were the Council of Supply Chain Management (CSCMP), Rsateleservices.com, and Lead411.com. Seven SIC codes are covered in the study: 22 "Textile Mill products", 23 "Apparel and other Textile Products", 25 "Furniture and Fixtures", 34 "Fabricated Metal Products", 35 "Industrial Machinery and Equipment", 36 "Electrical and Electronic Equipment", and 37 "Transportation Equipment". The lists were limited to organizations with more than 100 employees as these organizations are most likely to engage in sophisticated SCM initiatives.

The survey was conducted by the web-based method. The final version of the questionnaire (after purifying email lists) was administered by e-mail to 5498 target respondents. To ensure a reasonable response rate, the survey was e-mailed in three waves. In the first e-mail, the questionnaire with the cover letter indicating the purpose and significance of the study was emailed to target respondents. In the cover letter, the respondents were given three options to send their response: 1) online completion and submission: a web link was given so that they could complete the questionnaire online; 2) download the hard copy online: a link to the questionnaire in .pdf file was given and respondents could send it by fax or ask for a self-addressed stamped envelope; 3 ) request the hard copy by sending an email: they received in their regular mail a copy of the questionnaire along with a self-addressed stamped envelope. The response rate is calculated based on the number of click-through's the emailing has generated and total number that is converted to a completed survey. After three waves of emailing a total of 714 click-through's were generated and 294 completes were obtained to provide a good response rate of $41.18 \%$.

Response rate based on the click-through's may represent a better measure for email surveys, since bulk emails sent out in this manner may be treated as spam by a firm's email program and may never be retrieved or viewed by the target respondent. Since it is highly difficult to track this information accurately, a more appropriate measure would be to base the analysis on the number of people who have visited the site and have had an opportunity to review the request and purpose of this study, and then may have declined to complete the survey based on any number of reasons. Further, 11\% of the respondents are CEO/President, $45 \%$ are Vice Presidents, $25 \%$ are Directors, and $19 \%$ are titled as Managers. Thus $81 \%$ of the respondents are high level executives (CEOs, VPs, and Directors), implying a high reliability of the responses received, as these executives have a wider domain (job responsibility) and administrative knowledge. The areas of expertise were 11\% executives (CEOs/Presidents), $12 \%$ purchasing, 22\% SCM, 18\% distribution/transportation/logistics, 20\% manufacturing/production, 10\% materials, and $7 \%$ belong to other category such as sales. Thus the respondents' domains cover all key functions across the supply chain ranging from purchasing, to manufacturing, to sales, to distribution. Also, since $33 \%$ of the respondents have been with the organization over 10 years, $21 \%$ between $6-10$ years, and $27 \%$ between $2-5$ years, implies that 
majority of the respondents have a sound experience and comprehensive view of the supply chain program of their organization.

This research did not investigate non-response bias directly since the email lists had only names and email addresses of individuals without organizational details. This research compares those subjects who responded after the first e-mailing wave and those who responded to the second/third wave. The succeeding waves of survey were considered to be representative of non-respondents (Lambert and Harrington, 1990; Armstrong and Overton, 1977). Similar methodology has also been used in prior SCM empirical research (Li et al., 2005; Chen and Paulraj, 2004; Handfield and Bechtel, 2002). Chi-square tests $\left(\chi^{2}\right.$ statistic) were used to make the comparisons. No significant difference in industry type (based on SIC), employment size, and respondent's job title was found between these two groups (i.e. $\mathrm{p}>0.1$, when testing the null hypotheses: there is no significant difference in distribution of responses across SIC codes/employment size/job title between groups). Further, Chi-square tests of independence were also performed to observe if the distribution of responses across SIC codes, employment size, and respondent's job title is independent of the three waves when considered independently. No significant difference in industry type (based on SIC), employment size, and respondent's job title was found between each of the three groups / waves.

\section{RESULTS FOR MEASUREMENT MODEL}

In order to effectively test the structural model, it is essential to demonstrate that the instruments for the various constructs used in the study are valid and reliable. Instrument for supplier network responsiveness was developed and validated in this research, while instruments that measure information sharing (Li et al., 2005), and delivery dependability ( $\mathrm{Li}$ et al., 2005; Zhang, 2001) have been adopted from the respective literature. Convergent validity, discriminant validity, and reliability are important for construct validity (Ahire et al., 1996; Ragunathan and Ragunathan, 1994). Also, as per the guidelines of Bagozzi (1980) and Bagozzi and Phillips (1982), the important properties for measurement to be reliable and valid include content validity, construct validity (convergent and discriminant validity), reliability (internal consistency or scale consistency of operationalization), and predictive validity (we use the construct level correlation analysis). Structural equation modeling (AMOS) was used for convergent validity of supplier network responsiveness (measurement model) and discriminant (two constructs at a time) validity (of all three constructs used in this study). Reliability estimation is performed after convergent and discriminant validity because in the absence of a valid construct, reliability may not be relevant (Koufteros, 1999). Following are the discussions of content validity, convergent validity, discriminant validity, reliability analysis, and predictive validity.

\subsection{Convergent And Discriminant Validity}

Instrument assessment is an important step in testing the research model. CFA (confirmatory factor analysis) enables the elimination of unreliable items ensuring unidimensionality of multiple-item constructs (Bollen, 1989). AMOS software is used to perform CFA for the measurement model, which is then followed by the structural model displaying the hypothesized relationships. The proposed structural model was tested after the measurement model was found to be satisfactory, to avoid any interactions between the measurement and the structural model, and as proposed by Gerbing and Anderson (1988). The purification of the measurement model was done only to the supplier network responsiveness construct. Model-data fit was evaluated based on multiple fit indices. A GFI and AGFI score in the range of 0.8 to 0.89 is considered as representing a reasonable fit; a score of 0.9 or higher is considered as evidence of good fit (Joreskog and Sorbom, 1989). An RMSEA value of less than 0.05 indicates a good fit, a value as high as 0.08 represents reasonable errors of approximation in the population (Browne and Cudeck, 1993), a value ranging from 0.08 to 0.10 indicates mediocre fit, and values greater than 0.10 indicate poor fit (MacCallum et al., 1996). If the fit indices are not satisfactory, the modification indices are observed to check for any error term correlation. Model modification was carried out based on modification indices (MI). The threshold of MI is 4 chi-square statistics at a 0.05 significance level. High MI represents error covariances meaning that one item might share variance explained with another item (commonality) and thus they are redundant. The remedial action for error covariances is to delete such an item which has high error variance. Further, such items, whose error terms are highly correlated with the error terms of other items measuring that variable, are further studied for logic and theoretical support for deletion. Items are deleted one at a time if there was a reason to do so based on the criteria for model fit and based on theory. Otherwise the item remained in the model. This process of purification of the 
measurement model was continued until an acceptable model fit was obtained. The supplier network responsiveness (SNR) construct that emerged from the pilot study is represented by 6 items. These 6 items were submitted to a measurement model analysis to check model fit indices for each sub-construct to further refine the scale.

Appendix $\mathrm{C}$ reports the detailed purification process of the measurement model for supplier network responsiveness along with the final items. The items removed in the final instrument are marked by an asterisk (Appendices A and C).

After the purification, two items (SNR1 and SNR5) were dropped from supplier network responsiveness. The results are summarized in Table 2. The table presents the number of items measuring supplier network responsiveness, and the fit-statistics for the measurement model. The results indicate convergent validity for the supplier network responsiveness construct.

Table 2

Assessment of convergent validity for supplier network responsiveness

\begin{tabular}{lllllll}
\hline Construct & Items & $\chi^{2}$ & $\boldsymbol{P}$-value & GFI & AGFI & RMSEA \\
\hline Supplier network responsiveness & 4 & 4.37 & 0.11 & 0.99 & 0.96 & 0.06 \\
\hline
\end{tabular}

Discriminant validity was assessed to check if information sharing, supplier network responsiveness, and delivery dependability are truly dissimilar constructs. Discriminant validity can be assessed using structural equation modeling methodology (Bagozzi and Phillips, 1982). In AMOS, it can be done by taking two constructs at a time at one instance, and then having all items of the two constructs inserted into one single factor in the second instance. The chi-square values of running each instance thus obtained are noted. The difference between the chi-square value $(\mathrm{df}=1)$ of the two models must be greater than or equal to 3.84 for significance at $\mathrm{p}<0.05$ level so as to indicate support for the discriminant validity criterion (Joreskog, 1971). The constructs are considered to be distinct if the hypothesis that the two constructs together form a single construct is rejected. Table 3 provides discriminant validity results. The differences between chi-square values of all pairs and the corresponding single factors are statistically significant at $\mathrm{p}<0.0001$ level thus indicating high degree of discriminant validity among information sharing (IS), supplier network responsiveness (SNR), and delivery dependability (DD). Further, all pair-wise correlations between the constructs (Table 4) - information sharing, supplier network responsiveness and delivery dependability - are significantly different from 1, satisfying tests of discriminant validity and nomological validity (Nair, 2005).

Table 3

Assessment of Discriminant validity - pair-wise/single-factor comparison of chi-square values for information sharing, supplier network responsiveness, and delivery dependability

\begin{tabular}{|c|c|c|c|c|c|c|}
\hline \multirow[b]{2}{*}{$\begin{array}{c}\text { Construct } \\
\text { IS }\end{array}$} & \multicolumn{3}{|c|}{$\operatorname{IS}\left(\chi^{2}\right)$} & \multicolumn{3}{|c|}{$\operatorname{SNR}\left(\chi^{2}\right)$} \\
\hline & Pair-wise & $\begin{array}{l}\text { Single- } \\
\text { factor }\end{array}$ & Dif. & Pair-wise & Single-factor & Dif. \\
\hline SNR & 69.0 & 418.8 & 349.8 & & & \\
\hline DD & 55.1 & 394.8 & 339.7 & 14.6 & 323.2 & 308.6 \\
\hline
\end{tabular}

All $\chi^{2}$ differences are statistically significant at $\mathrm{p}<0.0001$ level

\subsection{Reliability}

The reliabilities of supplier network responsiveness, information sharing, and delivery dependability were assessed with Cronbach's (1951) alpha. A commonly used value for acceptable reliability is 0.70 (Hair et al., 1998; Nunnally, 1978). Table 4a-c reports means, standard deviations, correlations, and reliabilities for each of the constructs. The reliability values of all constructs are greater than 0.82 , which is considered good. 
Table 4

Means, standard deviations, correlations, and reliabilities of (a) information sharing, (b) supplier network responsiveness, and (c) delivery dependability

\begin{tabular}{|c|c|c|c|c|c|c|}
\hline Variables & Mean & S.D. & IS & SNR & DD & Reliability \\
\hline (a) Information sharing (IS) & 3.25 & .72 & - & & & 0.90 \\
\hline \multicolumn{7}{|l|}{ (b) Supplier network } \\
\hline responsiveness (SNR) & 3.33 & .70 & $0.33 * *$ & - & & 0.82 \\
\hline (c) Delivery dependability (DD) & 4.24 & .70 & $0.19 * *$ & $0.32 * *$ & - & 0.91 \\
\hline
\end{tabular}

**Correlation is significant at 0.01 level (two-tailed).

\subsection{Predictive Validity}

In order for the measurement to be generalized, predictive validity or criterion-related validity may be performed by comparing the construct with one or more external constructs. Criterion-related validity is characterized by prediction to an outside criterion and by checking a measuring instrument, against some outcome or measure (Kerlinger, 1986). In this study, the criterion used to test the predictive validity is dependent variable (also called as endogenous latent variable). Construct level correlation analysis was performed between the constructs to check for preliminary statistical validity of the hypotheses. Each construct was represented by a composite score. The composite score was computed by taking an average score of the multiple items under each construct as a score for that construct. Pearson correlation was then run between these composite scores for the latent first-order constructs (information sharing, supplier network responsiveness, and delivery dependability). Table 4 provides the results of the correlation analyses. All correlations between constructs were statistically significant at 0.01 level. Thus all three hypothesized relationships of interest are statistically supported by the Pearson correlation. Further hypotheses testing using structural equation modeling (using AMOS) is discussed in the next section.

\section{RESULTS OF STRUCTURAL MODELING AND HYPOTHESES TESTING}

The theoretical framework illustrated in Fig. 1 has three hypothesized relationships among variables information sharing, supplier network responsiveness, and delivery dependability. Fig. 2 displays the path analysis resulting from the AMOS structural modeling analysis. The results are presented in Table 5. The results exhibit that the model has good fit $\left(\chi^{2}=88.6, \mathrm{df}=51, P=0.001\right.$, GFI $=0.95$, AGFI $=0.93, \mathrm{CFI}=0.98$, and RMSEA $\left.=0.05\right)$. The results depict that hypotheses 1 and 2 are supported, while hypothesis 3 is not supported. The hypotheses testing results are discussed below.

Hypotheses $1(\mathrm{t}$-value $=5.19)$ and $2(\mathrm{t}$-value $=4.94)$, were both found to be significant at $P<0.001$ level. However, Hypothesis 3 (t-value $=0.65$ ) was not statistically significant $(P=0.26)$. Therefore, only research hypotheses 1 and 2 were found to be supported by the AMOS structural modeling results.

Table 5

Results for Structural model

\begin{tabular}{llllll}
\hline Hypothesis & Relationship & $\begin{array}{l}\text { Total effects } \\
\boldsymbol{\beta} \text { (t-value) }\end{array}$ & $\begin{array}{l}\text { Direct effects } \\
\boldsymbol{\beta} \text { (t-value) }\end{array}$ & $\begin{array}{l}\text { Indirect effects } \\
\boldsymbol{\beta} \text { (t-value) }\end{array}$ & Hypothesis \\
\hline $\mathrm{H} 1$ & IS $\rightarrow$ SNR & $0.36^{* * *}(5.19)$ & $0.36^{* * *}(5.19)$ & & Supported \\
$\mathrm{H} 2$ & $\mathrm{SNR} \rightarrow \mathrm{DD}$ & $0.36^{* * *}(4.94)$ & $0.36^{* * *}(4.94)$ & & Supported \\
$\mathrm{H} 3$ & $\mathrm{IS} \rightarrow \mathrm{DD}$ & $0.20^{* *}(3.09)$ & $0.07(1.13)$ & $0.13^{*}(1.963)$ & Not supported \\
\hline
\end{tabular}

*** Significant at $P<0.001$, ** Significant at $P<0.01$, * Significant at $P<0.05$ 
Hypotheses $1(\beta=0.36)$ and $2(\beta=0.36)$ have a medium (and almost large) effect size (standardized coefficient, $\beta<0.371$ ). The standardized structural coefficients (or effect size) between two constructs is commonly used to compliment structural equation modeling (SEM). An effect size of 0.371 or above is considered large, between 0.100 and 0.371 is considered medium, and 0.1 or below is considered small (Cohen, 1988; 1990). The effect size values confirm that the supported relationships have both statistical and practical significance, which are crucial in providing theoretical and managerial implications.

Hypothesis 1, which states that organizations with high levels of information sharing practices will have high levels of supplier network responsiveness is strongly supported $(\beta=0.36, P<0.001, \mathrm{t}=5.19)$. Hypothesis 1 confirms that organizations that are involved in information sharing initiatives with trading partners will create more responsive suppliers. Suppliers are benefited by the shared information by its downstream customer/s, enabling better customer service. This leads to better planning, reduced inventories, fewer stockouts, more accurate and ontime deliveries by suppliers, fewer quality defects, all meaning enhanced competitive capabilities and organizational performance for the supplier as well as the buyer.

The supported Hypothesis 2, indicates that supplier network responsiveness has a direct positive impact on delivery dependability of a firm $(\beta=0.36, P<0.001, \mathrm{t}=4.94)$. The finding empirically confirms the assertion in the literature (Milgate, 2000) that a responsive supplier could provide the organization (its immediate downstream customer) with enhanced delivery dependability capability. This should encourage organizations to collaborate (with partnerships and information sharing) with suppliers to meet customer demand in order to create a win-win position in the supply chain.

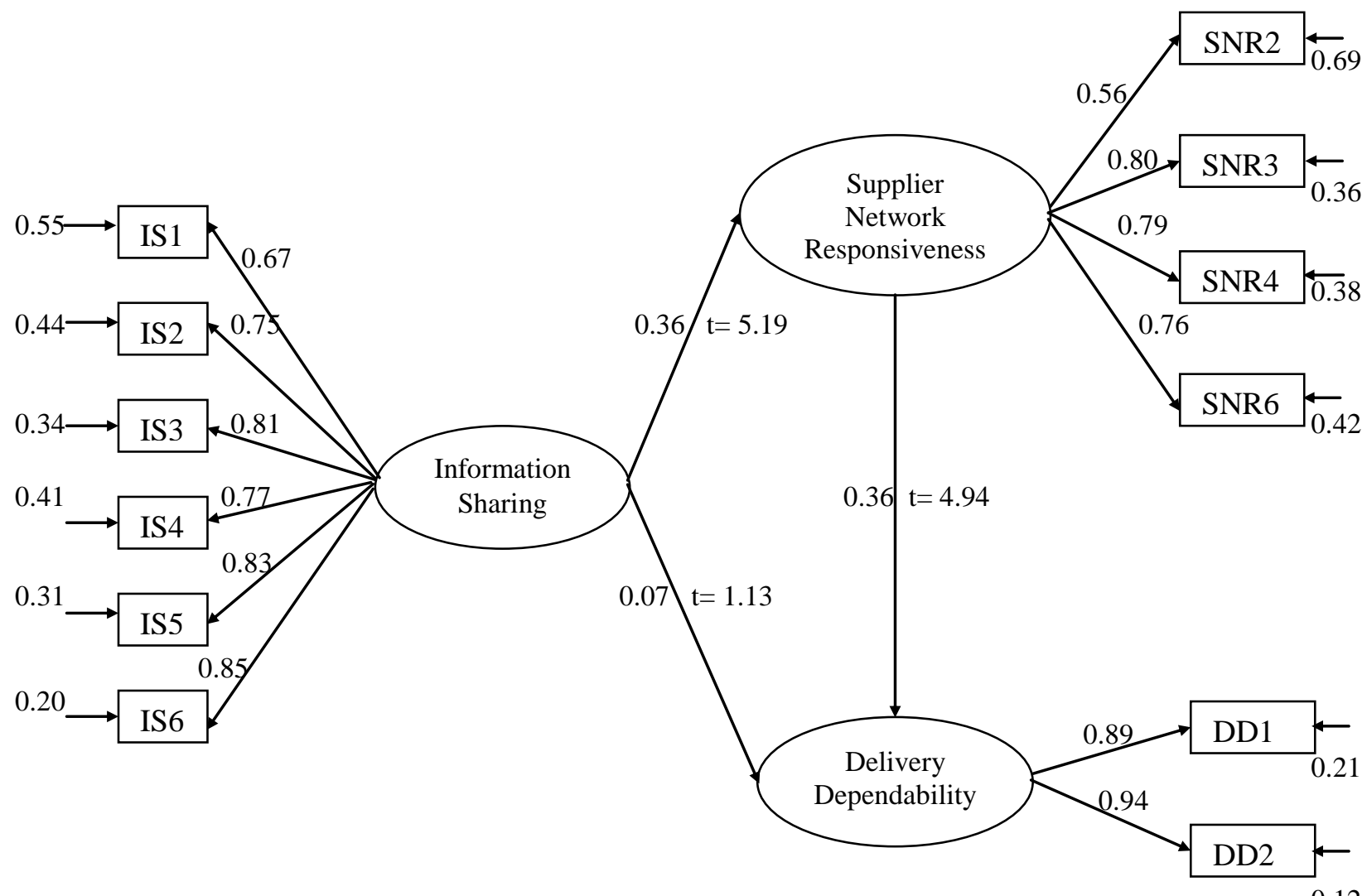

RMSEA $=0.05 . \mathrm{GFI}=0.95 . \mathrm{AGFI}=0.93 . \mathrm{CFI}=0.98$

Figure 2: AMOS structural model of information sharing, supplier network responsiveness, and delivery dependability 
The results do not support Hypothesis $3(\beta=0.07, P=0.26, \mathrm{t}=1.13)$, indicating that a firm's information sharing practices do not directly influence its level of delivery dependability. This implies that information sharing practice cannot improve the delivery dependability of a firm by itself, but only when it is supplemented by other best industry practices or characteristics which, when combined together can give the organization improved delivery performance. The results suggest that information sharing between trading partners although vital for the responsiveness of a firm's suppliers, may not be a sufficient criterion for creating and sustaining a long term improved delivery performance for the firm.

The results also indicate that delivery dependability of a firm is influenced by information sharing practices indirectly via supplier network responsiveness ( $\beta$ of indirect effect of information sharing on delivery dependability is $0.13, P<0.05, \mathrm{t}=1.963)$. This indicates that information sharing practices produce supplier network responsiveness in the first place, and supplier network responsiveness will in-turn, lead to improved delivery dependability for a firm. The findings of this research thus indicate the presence of in intermediate measure of supplier network responsiveness between information sharing and delivery dependability. In other words supplier network responsiveness mediates the relationship between information sharing and delivery dependability.

\section{RESEARCH FINDINGS AND IMPLICATIONS}

The results from this research can be used by academicians in further exploring and testing the causal linkages in supplier responsiveness and its advantages to a firm. The results can also be used by practitioners for developing mutual trust between trading partners, partnering/collaborating, and information sharing as well as evaluating supplier responsiveness and delivery dependability of their firm.

The results of this study have several important implications for researchers. First, supplier network responsiveness construct was developed and its measurement instrument validated which may be utilized for collecting data in future studies. The scale has been tested through rigorous statistical methodologies including pretest, pilot-test using Q-sort method, confirmatory factor analysis, unidimensionality, and reliability. The scale is shown to meet the requirements for reliability and validity and thus, can be used in future research. Such a valid and reliable scale has been otherwise lacking in the literature. The development of these measurements will greatly stimulate and facilitate the theory development in this field.

Second, this study supports literature (Tan, 2002; Hoetker et al., 2007; Milgate, 2000) regarding the relationship between information sharing initiatives and supplier responsiveness. The results demonstrate that a higher level of information sharing practices will lead to a higher level of supplier network responsiveness on an aggregate basis.

The results of this study also have important implications for practitioners. Attaining delivery dependability as one of the dimensions of competitive advantage is not a means to an end. The desired output is a satisfied customer rather than just a delivered product. The study confirms that firms that are involved in information sharing initiatives with suppliers can benefit from responsive suppliers. We observe that the benefits of information sharing are tightly linked with the presence of supplier network responsiveness. In essence, firms must synergize the practice of information sharing with suppliers with improved supplier responsiveness to enhance its own delivery performance.

While managers generally express belief in the potential for responsive suppliers, there is concern regarding how to implement such supply chain arrangements. Developing trust, long-term partnering, and information sharing are vital means by which organizations and managers can benefit from responsive suppliers. Such collaborative efforts in a supply chain can benefit both the buyer and the supplier, which is likely to bring down costs and boost profits.

The study also provides organizations a set of valid and reliable measurements for evaluating, benchmarking, and comparing supplier responsiveness at different nodes within the supply chain (i.e. raw material supplier, component supplier, assembler, sub-assembler, manufacturer, distributor, wholesaler, and retailer). The measurement for supplier network responsiveness developed in this research may be used by academicians and 
practitioners to identify the immediate outcomes of it, in addition to understanding its impacts on organizational performance.

\section{LIMITATIONS OF THE STUDY AND FUTURE RESEARCH}

This research has significant theoretical and practical contributions. It also has some limitations, which are described below. The examination of those limitations will assist future researchers to work around them.

In this research, individual respondents (high level executives from purchasing, operations, materials, and logistics functions) in an organization were asked to respond to complex SCM issues dealing with all the participants along the supply chain, including upstream suppliers and downstream customers. However, no person in an organization is in charge of the entire supply chain: for example, purchasing managers are mainly responsible for purchasing and supply side, and may be not in an appropriate position to answer the customer/delivery-related questions; the main area of manufacturing managers is production and they may not have enough knowledge of their suppliers and customers; similarly materials managers are mainly responsible for inventory and materials management, and they may not have enough knowledge of their customer. Therefore, the use of single respondent may generate some measurement inaccuracy.

The study is limited to the industries (SIC codes $-22,23,25,34,35,36,37$ ) used for this research. This could limit generalizability of results to other industry types. Future research can extended / replicate the study for other industry types to enhance generalizability. Recommendations for future research follow.

Future research may consider other relevant practices and initiatives such as strategic supplier partnership, customer relationship, postponement, and product/process modularity; new responsiveness dimensions such as operations system responsiveness and logistics responsiveness; and organizational characteristics such as organizational size, position in the supply chain, and number of tiers in the supply chain, that may significantly impact the delivery performance of a firm, which may be investigated or controlled for in future studies. Future studies may look into the effect of supplier responsiveness on specific dimensions of delivery performance such as cycle time, delivery speed, response accuracy, dispatch errors, and delivery consistency to get a bigger picture of the impact of supplier responsiveness on the overall delivery performance of a firm.

Appendix A. Instrument for information sharing, supplier network responsiveness, and delivery dependability

\begin{tabular}{cccccc}
\hline \multicolumn{5}{c}{ Scale } \\
\hline 1 & 2 & 3 & 4 & 5 & 6 \\
Not at all & To a small extent & To a moderate extent & To a considerable extent & To a great extent & Not applicable
\end{tabular}

Information Sharing (IS) (Adopted from Li et al., 2005; Li et al., 2006)

Please circle the number that accurately reflects the extent of your firm's current level of information sharing practices.

IS1 We inform trading partners in advance of changing needs

IS2 Our trading partners share proprietary information with us

IS3 Our trading partners keep us fully informed about issues that affect our business

IS4 Our trading partners share business knowledge of core business processes with us

IS5 We and our trading partners exchange information that helps establishment of business planning

IS6 We and our trading partners keep each other informed about events or changes that may

affect the other partners

Supplier Network Responsiveness (SNR)

Please circle the number that accurately reflects the extent of your supplier's current level of responsiveness. 
SNR1* Our major suppliers change product volume in a relatively short time

SNR2 Our major suppliers change product mix in a relatively short time

SNR3 Our major suppliers consistently accommodate our requests

SNR4 Our major suppliers provide quick inbound logistics to us

SNR5* Our major suppliers have outstanding on-time delivery record with us

SNR6 Our major suppliers effectively expedite our emergency orders

Delivery Dependability (DD) (Adopted from Zhang, 2001)

Please select the number that accurately reflects the extent of your firm's delivery dependability

DD1 We deliver customer orders on time

DD2 We provide dependable delivery

* Items were dropped in the final instrument

Appendix B. Demographic data of Respondents (sample size 294)

\begin{tabular}{|c|c|c|c|}
\hline \multirow[t]{2}{*}{ Variables } & Total Responses & First-wave & Second and third wave \\
\hline & Frequency (\%) & Frequency (\%) & Frequency $(\%)$ \\
\hline \multicolumn{4}{|c|}{ Industry - SIC (278) } \\
\hline SIC 22 & $0(0.0 \%)$ & $0(0.0 \%)$ & $0(0.0 \%)$ \\
\hline SIC 23 & $4(1.4 \%)$ & $2(2.3 \%)$ & $2(1.1 \%)$ \\
\hline SIC 25 & $7(2.5 \%)$ & $2(2.3 \%)$ & $5(2.6 \%)$ \\
\hline SIC 34 & $29(10.4 \%)$ & $9(10.3 \%)$ & $20(10.5 \%)$ \\
\hline SIC 35 & $28(10.1 \%)$ & $7(8.1 \%)$ & $21(11.0 \%)$ \\
\hline SIC 36 & $110(39.6 \%)$ & $36(41.4 \%)$ & $74(38.7 \%)$ \\
\hline SIC 37 & $26(9.4 \%)$ & $8(9.2 \%)$ & $18(9.4 \%)$ \\
\hline Other & $74(26.6 \%)$ & $23(26.4 \%)$ & $51(26.7 \%)$ \\
\hline \multicolumn{4}{|c|}{ Number of Employees (291) } \\
\hline $1-50$ & $12(4.1 \%)$ & $4(4.4 \%)$ & $8(4.0 \%)$ \\
\hline $51-100$ & $20(6.9 \%)$ & $6(6.6 \%)$ & $14(7.0 \%)$ \\
\hline $100-250$ & $35(12.0 \%)$ & $9(9.9 \%)$ & $26(13.0 \%)$ \\
\hline $251-500$ & $36(12.4 \%)$ & $10(11 \%)$ & $26(13.0 \%)$ \\
\hline $501-1000$ & $25(8.6 \%)$ & $7(7.7 \%)$ & $18(9.0 \%)$ \\
\hline Over 1000 & $163(56.0 \%)$ & $55(60.4 \%)$ & $108(54.0 \%)$ \\
\hline \multicolumn{4}{|l|}{ Job Title (290) } \\
\hline CEO/President & $31(10.7 \%)$ & $11(12.0 \%)$ & $20(10.1 \%)$ \\
\hline Vice President & $130(44.8 \%)$ & $37(40.2 \%)$ & $93(47.0 \%)$ \\
\hline Director & $73(25.2 \%)$ & $23(25.0 \%)$ & $50(25.3 \%)$ \\
\hline Manager & $56(19.3 \%)$ & $21(22.8 \%)$ & $35(17.7 \%)$ \\
\hline
\end{tabular}

Appendix C. Description of scale purification process and assessment of convergent validity of supply chain responsiveness constructs

\begin{tabular}{lll}
\hline Iteration & Items & Fit indices \\
\hline & & \multicolumn{1}{c}{ Supplier network responsiveness } \\
Initial model & SNR1, SNR2, SNR3, SNR4, & $\begin{array}{l}\chi^{2}=204.57 ; P=0.00 ; \text { GFI }=0.82 ; \text { AGFI = } \\
\text { RMSEA }=0.27\end{array}$
\end{tabular}


Although the $\lambda$ coefficients were satisfactory (above 0.64), RMSEA (0.27) is considerably high and AGFI (0.58) is substantially low. Modification indices indicated high error correlation between SNR1 and other items (SNR2, SNR4, SNR5, and SNR6). Hence item SNR1 was dropped for the next iteration.

Iteration $1 \quad$ SNR2, SNR3, SNR4, SNR5, SNR6

$$
\begin{aligned}
& \chi^{2}=24.74 ; P=0.00 ; \text { GFI }=0.97 ; \text { AGFI }=0.90 ; \\
& \text { RMSEA }=0.12
\end{aligned}
$$

RMSEA (0.12) is high. Modification indices indicated high error correlation between SNR5 and SNR6. Also, the $\lambda$ coefficient for SNR5 (0.72) was lower than that for SNR6 (0.81). Item SNR5 was thus dropped from the model.

Iteration $2 \quad$ SNR2, SNR3, SNR4, SNR6

$$
\begin{aligned}
& \chi^{2}=4.37 ; P=0.11 ; \mathrm{GFI}=0.99 ; \mathrm{AGFI}=0.96 ; \\
& \text { RMSEA }=0.06
\end{aligned}
$$

Although the $\lambda$ coefficient of SNR2 (0.57) was slightly lower, it was decided to keep the item as the overall model fit is good, with no error correlation between items. No further modifications were done. Items are listed below

Supplier network responsiveness (SNR)

SNR1* Our major suppliers change product volume in a relatively short time

SNR2 Our major suppliers change product mix in a relatively short time

SNR3 Our major suppliers consistently accommodate our requests

SNR4 Our major suppliers provide quick inbound logistics to us

SNR5* Our major suppliers have outstanding on-time delivery record with us

SNR6 Our major suppliers effectively expedite our emergency orders

* Items were dropped in the final instrument

\section{AUTHOR INFORMATION:}

Ashish Thatte is an Assistant Professor of Operations and Supply Chain Management in the School of Business Administration at Gonzaga University. He holds a Ph.D. in Manufacturing Management from the University of Toledo, Ohio. His research interests include supply chain management, operations management, and information systems issues in operations and supply chain. His research has appeared in refereed journals such as Journal of Retailing and Consumer Services, International Journal of Business Strategy, Review of Business Information Systems, and Review of Business Research.

Vikas Agrawal is an Assistant Professor in the Department of Management at Fayetteville State University. He received his PhD in Manufacturing Management and Engineering from the University of Toledo, Ohio. His primary teaching interest is in the area of Information Systems and Operations Management. He has published numerous papers in the areas of database management systems, data warehousing, knowledge management, optimization techniques, and supply chain management. His work has appeared in refereed journals such as Journal of Database Management, International Journal of Data Warehousing and Mining, Journal of International Technology and Information Management, Journal of Academy of Business and Economics, Review of Business Information Systems, International Journal of Operations and Quantitative Management and others.

Shahnawaz Muhammed is an Assistant Professor in the Department of Management at Fayetteville State University. Dr. Muhammed teaches information systems and operations management courses in his current position. His research interests include knowledge management, knowledge representation and information systems issues in supply chains. He holds a Ph.D. in Manufacturing Management from The University of Toledo and a B.Tech. in Mechanical Engineering from the University of Calicut, India. Prior to his academic position, his industry experience includes engineering design, software development and software testing. His work has appeared in refereed journals such as International Journal of Knowledge Management, Journal of Academy of Business and Economics, Review of Business Information Systems, and Review of Business Research. He is a Certified Supply Chain Professional (CSCP) by APICS. 


\section{REFERENCES}

1. Ahire, S. L., Golhar, D. Y., and Waller, M. A. (1996), "Development and Validation of TQM Implementation Constructs", Decision Sciences, 27(1), pp. 23-56.

2. Armstrong, J. S. and Overton, T. S. (1977), "Estimating Non-response Bias in Mail Surveys", Journal of Marketing Research (JMR), 14(3), pp. 396-402.

3. Asanuma, B. (1989), "Manufacturer-Supplier Relationships in Japan and the Concept of Relation-Specific Skill", Journal of the Japanese and International Economies, 3(1), pp. 1-30.

4. $\quad$ Bagozzi, R. P. (1980), Causal Models in Marketing, Wiley, New York

5. Bagozzi, R. P. and Phillips, L. W. (1982), "Representing and Testing Organizational Theories: A Holistic Construal", Administrative Science Quarterly, 27(3), pp. 459-489.

6. Ballou, R. H., Gillbert, S. M., and Mukherjee, A. (2000), "New Managerial Challenge from Supply Chain Opportunities", Industrial Marketing Management, 29, pp. 7-18.

7. Balsmeier, P. W. and Voisin, W. (1996), "Supply Chain Management: a Time-Based Strategy", Industrial Management, 38(5), pp. 24-27.

8. Bensaou, M. (1999), "Portfolios of Buyer-Supplier Relationships", Sloan Management Review, 40(4), pp. 35-44.

9. $\quad$ Blackburn, J. (1991), “Time-Based Competition”, Business One Irwin, Homewood, IL.

10. Bollen, K. A. (1989), Structural equations with latent variables, Wiley, New York.

11. Bowersox, D. J. (1990), “The Strategic Benefits of Logistics Alliances”, Harvard Business Review, 68(4), pp. 36-45.

12. Bowersox, D., Daugherty, P., Droge, C., Rogers, D., and Wradlow, D. (1989), “Leading Edge Logistics Competitive Positioning for the 1990's", Oakbrook, IL: Council of Logistics Management.

13. Brown, K. and Vastag, G. (1993), "Determinants of Manufacturing Delivery Reliability: A Global Assessment”, in Whybark, D.C., Vastag, G. (Eds), Global Manufacturing Practices, Elsevier, Amsterdam, pp. 285-304.

14. Browne, M. W. and Cudeck, R. (1993), "Alternative Ways of Assessing Model Fit", In K. A.

15. Bollen and J. S. Long (Eds.), Testing Structural Equation Models (pp. 445-455), Sage Publication, Newbury Park, CA.

16. Burt, D. N. and Soukup, W. R. (1985), "Purchasing's Role in New Product Development", Harvard Business Review, 63, pp. 90-97

17. Carr, A. S., Muthusamy, S. and Lee, P. D. (2008), "The Relationship between Intra-Organizational and Inter-Organizational Coordination and its Influence on Product Quality Improvement", Journal of Applied Business Research, Vol. 24(1), pp. 85-102

18. Chen, I. J. and Paulraj, A. (2004), "Towards A Theory of Supply Chain Management: The Constructs and Measurements", Journal of Operations Management, 22(2), pp. 119-50.

19. Cheraghi, S. H., Dadashzadeh, M. and Subramanian, M. (2004), "Critical Success Factors for Supplier Selection: An Update", Journal of Applied Business Research, 20(2), pp. 91-108

20. Choi T.Y. and Hartley J.L. (1996), "An Exploration of Supplier Selection Practices Across the Supply Chain”, Journal of Operations Management, 14(4), pp. 333-343.

21. Christopher, M. and Peck, H. (2004), "Building the Resilient Supply Chain", International Journal of Logistics Management, 15(2), pp. 1-13.

22. Clinton, S. R. and Closs, D. J. (1997), “Logistics Strategy: Does It Exist?”, Journal of Business Logistics, 18(1), pp. 19-44.

23. Cohen, J. (1960), "A Coefficient of Agreement for Nominal Scales", Educational and Psychological Measurement, Spring, pp.37-46.

24. Cohen, J. (1988), "Statistical Power Analysis for the Behavioral Sciences $\left(2^{\text {nd }}\right.$ ed.), Lawrence Erlbaum, Hillsdale, NJ

25. Cohen, J. (1990), “Things I Have Learned (So Far)”, American Psychologist (12), pp. 1304-1312.

26. Cooper, M. and Gardner, J. (1993), "Good Business Relationships: More than Just Partnerships or Strategic Alliances”, The International Journal of Physical Distribution and Logistics Management, 23(6), pp. 4-26.

27. Cronbach, L. J. (1951), "Coefficient Alpha and the Internal Structure of Tests", Psychometrika, 16, pp. 297-335. 
28. De Toni, A. and Nassimbeni, G. (1999), "Buyer-supplier operational practices, sourcing policies and plant performance: result of an empirical research", International Journal of Production Research, 37, pp. 597619.

29. Duclos, L. K.., Vokurka, R. J., and Lummus, R. R. (2003), “A Conceptual Model of Supply Chain Flexibility”, Industrial Management \& Data Systems, 103(6), pp. 446-456.

30. Emerson, C. and Grimm, C. (1998), "The Relative Importance of Logistics and Marketing Customer Service: A Strategic Perspective”, Journal of Business Logistics, 19(1), pp. 17-32.

31. Fawcett, S. E. (1992), "Strategic Logistics in Coordinated Global Manufacturing Success", International Journal of Production Research, 30(5), pp. 1081-2000.

32. Fawcett, S. E. and Smith, S. R. (1995), "Logistics Measurement and Performance for United StatesMexican Operations under NAFTA", Transportation Journal, 34(3), pp. 25-34.

33. Fawcett, S. E., Calantone, R., and Smith, S. R. (1996), "An Investigation of the Impact of Flexibility on Global Reach and Firm Performance”, Journal of Business Logistics, 17(2), pp. 168-196.

34. Fawcett, S. E., Calantone, R., and Smith, S. R. (1997), "Delivery Capability and Firm Performance in International Operations”, International Journal Production Economics, 51, pp. 191-204.

35. Ferdows, K., and DeMeyer, A. (1990), "Lasting Improvements in Manufacturing Performance: In Search of a New Theory", Journal of Operations Management, 9, pp. 168-184.

36. Fisher M.L., Raman A., and Mcclelland A.S. (2000), "Rocket Science Retailing is Almost Here: Are You Ready?", Harvard Business Review, 78(4), pp. 115-124.

37. Fredericks, E. (2005), "Infusing Flexibility into Business-To-Business Firms: A Contingency Theory and Resource-Based View Perspective and Practical Implications”, Industrial Marketing Management, 34(6), pp. 555-565.

38. Frohlich, M.T. and Westbrook, R. (2001), “Arcs of Integration: An International Study of Supply Chain Strategies”, Journal of Operations Management, 19(2), pp. 185-200.

39. Gerbing, D. W. and Anderson, J. C. (1988), "Evaluating Structural Equation Methods, Number of Indicators per Factor, and Improper Solutions on Structural Equation Modeling Fit Indices”, Structural Equation Modeling, 2(2), pp. 119-144

40. Golden, W. and Powell, P. (1999), "Exploring Inter-Organisational Systems and Flexibility in Ireland: A Case of Two Value Chains", International Journal of Agile Management Systems, 1(3), pp. 169-176.

41. Gosain, S., Malhotra, A., and El Sawy, O. A. (2005), "Coordinating for Flexibility in e-Business Supply Chains”, Journal of Management Information Systems, 21(3), pp. 7-45.

42. Hair, J. F., Anderson, R. E., Tatham, R. L., and Black, W. C. (1998), Multivariate Data Analysis, Fifth Edition, Macmillan Publishing Company, New York, NY.

43. Hall, R. W. (1993), “A Framework for Linking Intangible Resources and Capabilities to Sustainable Competitive Advantage", Strategic Management Journal, 14(8), pp. 607-618

44. Hall, R. W., Johnson, H. T., and Turney, P. B. B. (1991), "Measuring Up: Charting Pathways to Manufacturing Excellence", Business One Irwin, Homewood, IL.

45. Handfield, R. B. and Bechtel, C. (2002), "The Role of Trust and Relationship Structure in Improving Supply Chain Responsiveness", Industrial Marketing Management, 4(31), pp. 367-382

46. Hill. T. (2000), Manufacturing Strategy, Irwin McGraw-Hill, Boston, MA.

47. Hoetker, G., Swaminathan, A., and Mitchell, W. (2007), "Modularity and the Impact of Buyer--Supplier Relationships on the Survival of Suppliers", Management Science, 53(2), pp. 178-191.

48. Holweg, M. (2005), “An Investigation into Supplier Responsiveness”, International Journal of Logistics Management, 16(1), pp. 96-119.

49. Holweg, M. and Pil, F. K. (2001), "Successful Build-To-Order Strategies Start with the Customer", MIT Sloan Management Review, 43(1), pp. 74-84.

50. Jones, C. (1998), “Moving Beyond ERP: Making the Missing Link”, Logistics Focus, 6(7), pp. 2-7.

51. Jordan J. A. and Michel F. J. (2000), Next Generation Manufacturing: Methods and Techniques, John Wiley and Sons, New York, NY.

52. Joreskog, K. G. (1971), "Statistical Analysis of Sets of Congeneric Tests”, Psychometrika, 36(2), pp. 109133.

53. Joreskog, K. G. and Sorbom D. (1989), LISREL 7 Users' Reference Guide, Scientific Software Inc., Chicago, IL. 
54. Karpak, B., Kasuganti, R. R., Kumcu, E. (1999), "Multi-Objective Decision-Making in Supplier Selection: An Application of Visual Interactive Goal Programming", Journal of Applied Business Research, 15(2), pp. 57-72

55. Kerlinger, F. N. (1986), Foundations of Behavioural Research, 3rd Ed., Holt, Rinehart and Winston, New York.

56. Koufteros, X. A. (1999), “Testing a Model of Pull Production: A Paradigm for Manufacturing Research Using Structural Equation Modeling”, Journal of Operations Management, 17(4), pp. 467-488.

57. Koufteros, X. A., Vonderembse, M. A., and Doll, W. J. (2002), "Examining the Competitive Capabilities of Manufacturing Firms", Structural Equation Modeling, 9(2), pp. 256-282.

58. Koufteros, X. A., Vonderembse, M. A., and Doll, W. J., (1997), “Competitive Capabilities: Measurement and Relationships”, Proceedings Decision Science Institute 3, pp.1067-1068.

59. Lalonde, B. J. (1998), "Building a Supply Chain Relationship", Supply Chain Management Review, 2(2), pp. 7-8.

60. Lambert, D. M. and Harrington, T. C. (1990), "Measuring Non-response Bias in Customer Service Mail Surveys", Journal of Business Logistics, 11(2), pp. 5-25.

61. Lancioni, R. A., Smith, M. F., and Oliva, T. A. (2000), "The Role of the Internet in Supply Chain Management”, Industrial Marketing Management, 29, pp. 45-56.

62. Lau, R. S. M. (1999), "Critical Factors for Achieving Manufacturing Flexibility”, International Journal of Operations and Production Management, 19(3/4), pp. 328-341

63. Lee, H., and Whang, S. (2001), "E-Business and Supply Chain Integration," Stanford Global Supply Chain Management Forum, Stanford University Report, Stanford, CA.

64. Lee, H., Padmanabhan, V., and Whang, S. (1997), “The Bullwhip Effect in Supply Chains," Sloan Management Review, 38, pp. 93-102.

65. Li, S., Ragu-Nathan, B., Ragu-Nathan, T. S., and Rao, S. Subba (2006), "The Impact of Supply Chain Management Practices on Competitive Advantage and Organizational Performance", Omega, 34(2), pp. 107-124.

66. Li, S., Rao, S. Subba, Ragu-Nathan, T. S., and Ragu-Nathan, B. (2005), "Development and Validation of A Measurement Instrument for Studying Supply Chain Management Practices”, Journal of Operations Management, 23(6), pp. 618-641.

67. Liu, E. R. and Kumar, A. (2003), "Leveraging Information Sharing to Increase Supply Chain Configurability", Twenty Fourth International Conference on Information Systems, pp. 523-537.

68. Lummus, R. R. and. Vokurka, R. J. (1999), “Defining Supply Chain Management: A Historical Perspective and Practical Guidelines", Industrial Management \& Data Systems, 99(1), pp. 11-17.

69. Lummus, R. R., Duclos, L. K., and Vokurka, R. J. (2003), "Supply Chain Flexibility: Building a New Model”, Global Journal of Flexible Systems Management, 4(4), pp. 1-13.

70. Lummus, R. R., Vokurka, R. J., and Duclos, L. K. (2005), "Delphi Study on Supply Chain Flexibility", International Journal of Production Research, 43(13), pp. 2687-2708.

71. MacCallum, R. C., Browne, M. W., and Sugawara, H. M. (1996), "Power Analysis and Determination of Sample Size for Covariance Structure Modeling”, Psychological Methods, 1, pp. 130-149.

72. Manna, Dean R. (2008), "Just-In-Time: Case Studies of Supplier Relationships across Industries", Journal of Applied Business Research, 24(1), pp. 75-83

73. Martin, J. H. and Grbac, B. (2003), "Using supply chain management to leverage a firm's market orientation”, Industrial Marketing Management, 32(1), pp. 25-38

74. Mason S. J., Cole M. H., Ulrey B. T., and Yan, L. (2002), "Improving Electronics Manufacturing Supply Chain Agility through Outsourcing, International Journal of Physical Distribution and Logistics Management, 32(7), pp. 610-620.

75. McGinnis M. A. and Vallorpa R. M. (1999), "Purchasing and Supplier Involvement: Issues and Insights Regarding New Product Success", Journal of Supply Chain Management, 35(3), pp. 4-15.

76. Mentzer, J. T., Foggin, J. H. and Golicic, S. L. (2000), “Collaboration: the Enablers, Impediments, and Benefits", Supply Chain Management Review, Sept/Oct.

77. Milgate, M. (2000), "Antecedents of Delivery Performance: An International Exploratory Study of Supply Chain Complexity”, Irish Marketing Review, 2000, 13(2), pp. 42-54.

78. Monczka, R. M., Petersen, K. J., Handfield, R. B., and Ragatz, G. L. (1998), "Success Factors in Strategic Supplier Alliances: the Buying Company Perspective”, Decision Science, 29(3), pp. 5553-5577. 
79. Moore, G. and Benbasat, I. (1991), "Development of an Instrument to Measure the Perceptions of Adopting an Information Technology Innovation", Information Systems Research, 2(3), pp. 192-222

80. Nair, A. (2005), "Linking Manufacturing Postponement, Centralized Distribution and Value Chain Flexibility with Performance", International Journal of Production Research, 43(3), pp. 447-463.

81. Narsing, A. (2005), "RFID and Supply Chain Management: An Assessment of its Economic, Technical, and Productive Viability in Global Operations", Journal of Applied Business Research, Vol. 21(2), pp. 7580

82. Nemetz, P. (1990), "Bridging the Strategic Outcome Measurement Gap in Manufacturing Organizations", in Ettlie, J., Burstein, M., and Fiegenbaum, A. (Eds.), Manufacturing Strategy, Norwell, MA: Kluwer Academic, pp. 63-74.

83. Novack, R. A., Langley, C. J. Jr., and Rinehart, L. M. (1995), “Creating Logistics Value: Themes for the Future", Oak Brook, IL: Council of Logistics Management.

84. Nunnally, J. C. (1978), Psychometric Theory, McGraw-Hill, New York, NY.

85. Peleg, B., Lee, H. L., and Hausman, W. H. (2002), "Short-Term E-Procurement Strategies versus LongTerm Contracts", Production \& Operations Management, 11(4), pp. 458-479.

86. Prater, E., Biehl, M., and Smith, M. A. (2001), "International Supply Chain Agility”, International Journal of Operations \& Production Management, 21(5/6), pp. 823-840.

87. Raghunathan, B. and Raghunathan, T. S. (1994), "Adaptation of a Planning System Success Model to Information Systems Planning", Information Systems Research, 5(3), pp. 326-340.

88. Rich, N. and Hines, P. (1997), "Supply-Chain Management and Time-Based Competition: The Role of the Supplier Association", The International Journal of Physical Distribution and Logistics Management, 27(3-4), pp. 210-226.

89. Rondeau, P. J., Vonderembse, M. A., and Ragu-Nathan, T. S., (2000), "Exploring Work System Practices for Time-Based Manufacturers: Their Impact on Competitive Advantage", Journal of Operations Management, 18, pp. 509-529.

90. Rossetti, C. and Choi, T.Y. (2005), "On the Dark Side of Strategic Sourcing: Experiences from the Aerospace Industry", Academy of Management Executive, 19(1), pp. 46-60.

91. Roth, A. and Miller, J. (1990), "Manufacturing Strategy, Manufacturing Strength, Managerial Success, and Economic Outcomes", in Ettlie, J., Burstein, M., and Fiegenbaum, A. (Eds.), Manufacturing Strategy, Norwell, MA: Kluwer Academic, pp. 97-108.

92. Ryu, S and Cook, M. (2005), "The Effect of LTO Culture on International Supply Chain Contracts", Journal of Applied Business Research, Vol. 21(4), pp. 95-105.

93. Schmenner, R.W. and Tatikonda, M. V. (2005), "Manufacturing Process Flexibility Revisited", International Journal of Operations \& Production Management, 25(12), pp. 1183-1189.

94. Shapiro, P., Rangan, V., and Sviokla, J. (1982), "Staple Yourself to an Order", Harvard Business Review, pp. 113-122.

95. Simatupang, T. M. and Sridharan, R. (2002), "The Collaborative Supply Chain", International Journal of Logistics Management, 13(1), pp. 15-30.

96. Simatupang, T. M. and Sridharan, R. (2005), "An Integrative Framework for Supply Chain Collaboration”, International Journal of Logistics Management, 16(2), pp. 257-274.

97. Singh, K. and Mitchell, W. (1996), "Precarious Collaboration: Business Survival After Partners Shut Down or Form New Partnerships", Strategic Management Journal, 17(7), pp. 99-115.

98. Slack, N. (1991), The Manufacturing Advantage, Mercury Books, London.

99. Soosay, C. A. and Chapman, R. L. (2006), "An Empirical Examination of Performance Measurement for Managing Continuous Innovation in Logistics", Knowledge and Process Management, 13(3), pp. 192-205

100. Srivastava, S.K. (2006), "Logistics and Supply Chain Practices in India", The Journal of Business Perspectives", 10(3), pp. 69-79.

101. Stein, T. and Sweat, J. (1998), "Killer Supply Chains", Information Week, 708(9), pp. 36-46.

102. Swink, M. and Zsidisin, G. (2006), "On the Benefits and Risks of Focused Commitment to Suppliers", International Journal of Production Research, 44(20), pp. 4223-4240.

103. Tompkins, J. and Ang, D. (1999), "What are Your Greatest Challenges Related to Supply Chain Performance Measurement?", IIE Solutions, 31(6), pp. 66.

104. Towill, D. R. (1997), “The Seamless Chain- the Predator's Strategic Advantage”, International Journal of Technology Management, 13(1), pp. 37-56. 
105. Van der Vorst, J. G. A. J. and Beulens, A. J. M. (2002), "Identifying Sources of Uncertainty to Generate Supply Chain Redesign Strategies", International Journal of Physical Distribution \& Logistics Management, 32(6), pp. 409-430.

106. Van Hoek, R. I. (2000), "The Role of Third-Party Logistics Providers in Mass Customization", International Journal of Logistics Management, 11(1), pp. 37-47.

107. Vokurka, R. J. and Lummus, R. R. (2000), "The Role of Just-in-Time in Supply Chain Management", International Journal of Logistics Management, 11(1), pp. 89-98.

108. Walker, W. T. (2005), "Supply chain Flexibility", ASCET Supply Chain White Paper.

109. Yu, Z. X., Yan, H., and Cheng, T. C. E. (2001), "Benefits of Information Sharing with Supply Chain Partnerships", Industrial Management and Data Systems, 101(3), pp. 114-119.

110. Zhang, Q. Y. (2001), “Technology Infusion Enabled Value Chain Flexibility: A Learning and CapabilityBased Perspective", Doctoral Dissertation, University of Toledo, Toledo, OH.

111. Zhang, Q., Vonderembse, M. A., and Lim, J. S. (2002), "Value Chain Flexibility: A Dichotomy of Competence and Capability", International Journal of Production Research, 40(3), pp. 561-583.

\section{$\underline{\text { NOTES }}$}

